\title{
Kelompok Vigilante sebagai Exit Institution: Friksi antara Brigade Manguni dan Gereja Masehi Injili Minahasa (GMIM) Pasca Reformasi (2000-2010)
}

\section{Daniel Andara Kalangie ${ }^{1}$}

\begin{abstract}
Abstrak
Tulisan ini mencoba untuk melihat proses kehadiran kelompok vigilante bernama Brigade Manguni dalam masyarakat Minahasa pasca reformasi. Berbeda dari beberapa studi terdahulu yang melihat kehadiran kelompok vigilante dalam konteks relasi negara dan masyarakat, Brigade Manguni (BM) hadir sebagai faksi dari institusi keagamaan, yaitu gereja dalam masyarakat Minahasa-Kristen, atau Gereja Masehi Injili Minahasa (GMIM). Faksi tersebut hadir untuk mempertahankan identitas MinahasaKristen saat peristiwa Konflik Poso antara kelompok Kristen dan Islam yang menyebabkan banyak korban dari pihak Kristen. Penelitian ini menggunakan pendekatan Siegel dan Beals (1960) dalam memahami faksi sebagai disrupsi terhadap cara kerja struktur dominan dalam masyarakat. Hasil penelitian ini menunjukkan bahwa BM sebagai faksi memainkan peran sebagai "Exit Institution", yaitu institusi yang mampu menawarkan jalan keluar dari cara diskursif menuju cara-cara kekerasan dalam upaya mempertahankan identitas. Menggunakan metode penelitian kualitatif, kasus BM dapat menjadi konteks alternatif untuk memahami kelompok vigilante di Indonesia pasca reformasi.
\end{abstract}

Kata kunci: Kelompok Vigilante; Minahasa, Brigade Manguni; Konflik Komunal; Gereja Masehi Injili Minahasa; Exit Institution.

1 Mahasiswa Departemen Politik dan Pemerintahan, Fakultas Ilmu Sosial dan Ilmu Politik, Universitas Gadjah Mada. 


\section{PENDAHULUAN}

"Pak pendeta, ini so dua kali Tuhan nyanda balas-balas. Biar jo torang yang balas! (Pak pendeta, sudah dua kali Tuhan tidak membalaskan [dendam] kami. Biar kami saja yang membalasnya!)"

(Anonim, 2000)

Tulisan ini melihat peran kelompok vigilante bernama Brigade Manguni (BM) yang hadir melalui terbentuknya faksi dari institusi keagamaan dalam masyarakat Minahasa pasca reformasi, yaitu Gereja Masehi Injili Minahasa (GMIM). BM tidak diamati dalam konteks relasi negara dan masyarakat yang merupakan konteks utama dalam pengamatan terdahulu tentang kelompok vigilante di Indonesia. BM dalam tulisan ini diamati sebagai fenomena faksionalisme. Tulisan ini menggunakan pendekatan Siegel dan Beals (1960) untuk menjelaskan faksi sebagai disrupsi terhadap cara kerja struktur dominan dalam masyarakat. Pendekatan tersebut berguna untuk mengamati penggunaan kekerasan oleh BM yang mendisrupsi peran GMIM sebagai struktur dominan dalam masyarakat Minahasa saat peristiwa konflik Poso ketiga. Konteks konflik Poso ketiga dan faksi dalam GMIM menunjukkan bahwa BM berperan sebagai "Exit Institution", yaitu institusi yang mampu menawarkan jalan keluar cara diskursif menuju 
cara-cara kekerasan dalam upaya mempertahankan identitas.

Frasa pada bagian awal tulisan ini merupakan penggalan dari anekdot yang beredar dalam komunitas masyarakat Kristen saat peristiwa konflik Poso III. Anekdot ini menceritakan momen pembalasan kelompok Kristen terhadap kelompok Islam di Poso pada pertengahan tahun 200o. Konflik Poso merupakan salah satu konflik komunal yang terjadi di Indonesia pasca reformasi (lihat Aditjondro, 2004). Konflik Poso mencerminkan kondisi sosial politik Indonesia dalam periode pasca reformasi yang banyak ditandai oleh konflik komunal. ${ }^{2}$ Sidel (2007) menilai hal ini merupakan refleksi dari memuncaknya usaha Islamisasi di Indonesia pasca reformasi. Walaupun etnis Minahasa-Kristen menjadi kelompok yang paling dominan di Provinsi Sulawesi Utara yang heterogen, dalam konteks nasional, kelompok ini masih termasuk minoritas. Hal inilah yang menjadi sumber keresahan mereka saat meledaknya

2 Lebih jauh tentang beberapa konflik komunal di Indonesia pasca reformasi lihat: van Klinken, Gerry. (2007). Communal Violence and Democratization in Indonesia: Small Town Wars. Routledge. 
konflik Poso. ${ }^{3}$ Henley menyebutkan bahwa melekatnya aspek kekristenan dalam identitas etnik Minahasa telah menjadikan keminahasaan sebagai identitas komunal yang berbeda serta rentan "dipinggirkan" melalui usaha Islamisasi di Indonesia (Henley, 1993; Karim, 2020). Selanjutnya, menjelaskan kedekatan geografis Sulawesi Utara dengan lokasi konflik seperti Poso turut membuat pengaruh konflik sangat terasa bagi komunitas Minahasa-Kristen (Henley, 2007).

Beberapa studi terdahulu mencatat bahwa keminahasaan di tengah pengaruh konflik berhasil dipertahankan tanpa kekerasan (Henley et.al., 2007; Sumampouw, 2015; Karim, 2020). Henley et.al., 2007) menjelaskan alasan di balik keberhasilan ini terletak pada peran sentral masyarakat sipil terutama GMIM (Gereja Masehi Injili Minahasa). GMIM berhasil membangun koordinasi kelompok lintas agama yang solid untuk meredam potensi konflik horizontal. ${ }^{4}$ Koordinasi masyarakat sipil oleh GMIM juga diikuti

3 Menurut catatan BPS pada tahun 2000, jumlah etnis Minahasa yang tersebar di seluruh Provinsi Sulawesi Utara berjumlah 659.204 dari total penduduk. Walaupun angka ini berada di bawah jumlah etnis Gorontalo (897.234), namun etnis Gorontalo hanya terpusat di wilayah administratif Kota Gorontalo, Kabupaten Gorontalo, dan Kabupaten Boalemo. Jika memperhatikan konteks berpisahnya beberapa wilayah ini dari Sulawesi Utara menjadi Provinsi Gorontalo dengan mayoritas penduduk beragama Islam pada tahun yang sama, maka etnis Minahasa secara jumlah menjadi etnis terbesar di Provinsi Sulawesi Utara terutama di Manado sebagai ibukota provinsi.

4 GMIM merupakan sinode gereja dengan jumlah jemaat terbesar di Sulawesi Utara. Lebih lanjut lihat: Makello, Ilham Daeng. (2010). Kota Seribu Gereja: Dinamika Keagamaan Dan Penggunaan Ruang Di Kota Manado. Yogyakarta: Ombak. 
dengan usaha mewacanakan ajakan untuk berdamai di tengah ancaman konflik. Salah satu pesan yang dominan disampaikan oleh GMIM adalah slogan "Torang Samua Basudara” (kita semua bersaudara) (Sumampouw, 2015). ${ }^{5}$ Sentralnya peran GMIM didukung oleh kuatnya legitimasi gereja sebagai bentuk pelembagaan aspek kekristenan sejak kedatangan misionaris Belanda Nederlansche Zendeling Genootschap (NZG) di Minahasa (Henley, 1993). Hal ini membuat gereja, khususnya GMIM, menjadi struktur sosial politik yang dominan dalam kehidupan etnis Minahasa (Schouten, 1998). Pentingnya peran GMIM ditunjukkan oleh keberhasilannya dalam mewakilkan aspirasi etnis Minahasa secara diskursif. GMIM bekerja melalui persuasi untuk menjaga komunitas Minahasa-Kristen tanpa melakukan konfrontasi terhadap kelompok lain (lihat: Henley et.al., 2007). Cara tersebut telah menjadi solusi yang dominan dalam merespons pengaruh konflik bagi komunitas Minahasa-Kristen di era pasca reformasi. ${ }^{6}$

5 Torang Samua Basudara (Terjemahan: Kita Semua Bersaudara) merupakan slogan yang diwacanakan secara luas di Sulawesi Utara pada pertengahan 200oan untuk meredam pengaruh konflik komunal dari Maluku dan Poso. Lihat: Sumampouw, Nono. (2015). Menjadi Manado Torang Samua Basudara, Sabla Aer, dan Pembentukan Identitas Sosial. Yogyakarta: Gadjah Mada University Press.

6 Yulianto (2015) bahkan menjelaskan kekristenan-dan juga ke-Barat-an-telah menjadi elemen yang melekat dalam keminahasaan itu sendiri. Lihat: Yulianto, Vissia Ita. (2015). Reframing Modernities in Contemporary Indonesia: Ethnographic Studies of Ideas of Center and Periphery on Sulawesi and Java. Berlin: Regiospectra Verlag. 
Namun dalam periode yang sama, terdapat kelompok vigilante berbasis identitas Minahasa-Kristen bernama Brigade Manguni (BM).7 $\mathrm{BM}$ merupakan organisasi masyarakat (ormas) adat Minahasa pertama yang berdiri pada pertengahan tahun 2000. ${ }^{8}$ Kelompok ini menggunakan kekerasan dalam merespons ancaman konflik komunal. Peran BM dapat diamati dalam fase ketiga konflik Poso untuk membela kelompok Kristen (Sangadji, 2007; McRae, 2008; Bakker, 2012). Dalam konteks yang demikian, tulisan ini menjawab pertanyaan mengapa kelompok vigilante seperti BM juga turut hadir dari latar belakang keadaan sosial politik Minahasa yang damai? Dengan melakukan penelitian secara kualitatif, tulisan ini menunjukkan peran BM sebagai exit institution melalui faksionalisme dalam GMIM. Tulisan ini menjelaskan definisi exit institution sebagai institusi yang mampu menawarkan jalan keluar baru dari dominasi cara diskursif menuju cara kekerasan dalam menjaga keminahasaan.

7 Johnston (1996) menilai vigilantism yang merupakan karakteristik dasar kelompok vigilante lahir dari pelanggaran norma yang terlembaga baik oleh individu maupun kelompok. Dengan kata lain kelompok vigilante berkaitan dengan fenomena penggunaan kekerasan oleh warga negara dan rasa tanggung jawab terhadap sebuah tatanan sosial. Lebih lanjut tentang konsep vigilantism sebagai watak dasar kelompok vigilante, lihat: Johnston, Les. (1996). ”What is Vigilantism?”. British Journal of Criminology 36. Oxford University Press. 220-36.

8 Penggunaan istilah Manguni diambil dari burung hantu/celepuk Sulawesi (otus manadensis) yang dipercaya merupakan manifestasi Tuhan Yang Maha Esa atau Opo Empung dalam mitologi masyarakat Minahasa pra-modern. 
Peran BM sebagai exit institution dapat ditemukan melalui pendekatan konseptual dalam menjelaskan faksi menurut Siegel dan Beals (1960). Konsep ini digunakan karena peran BM sebagai exit institution hadir melalui faksionalisme dari struktur dominan dalam masyarakat Minahasa-Kristen, yaitu gereja atau GMIM. Faksi patut dicermati sebagai proses disruptif terhadap usaha kooperasi dalam suatu kelompok dominan di tengah masyarakat untuk mencapai tujuan bersama (Siegel dan Beals, 1960). Pemahaman tersebut tidak dapat dilepaskan dari pengaruh strukturalfungsionalis yang ingin memperlebar pembahasan awal Fortes dan Pritchard tentang pemisahan elit politik dalam masyarakat kesukuan di Afrika (1940). Dalam perkembangannya, Nicholas (1966) mempertegas bahwa faksi merupakan sebuah aktifitas politik. ${ }^{9}$ Bagi Nicholas (1966) faksi ditandai oleh konflik terorganisir untuk merebut kuasa atas publik. Hadirnya faksi menunjukkan adanya goncangan terhadap struktur dominan dalam masyarakat. Karena itu, Siegel dan Beals (1960) mencermati bahwa terjadinya faksi merupakan disrupsi terhadap bekerjanya fungsi dari sebuah struktur dalam sistem sosial.

9 Nicholas (1966) mengakui pengaruh konseptual Siegel dan Beals (1960) dalam tulisannya untuk menjelaskan faksi sebagai kegiatan politik. Lihat: Nicholas, Ralph. W. (1966). "Segmentary Factional Political System.” Dalam Marc J. Schawrtz, Victor W. Turner, Arthur Tuden (Eds), Political Anthropology, (pp. 49-6o). Chicago: Aldine Publishing. 
Siegel dan Beals (1960) menjelaskan bahwa terdapat dua faktor utama terbentuknya sebuah faksi. Yang pertama adalah posisi kelompok sebagai bagian dari sistem sosial terhadap lingkungan luarnya (stress). Hal kedua adalah perbedaan internal terkait cara yang dapat disepakati untuk merespons dampak eksternal terhadap kelompok itu sendiri (strains). Interaksi antara kedua faktor ini memungkinkan terbentuknya faksi dalam sebuah kelompok. Faksionalisme tidak merujuk pada ketidaksepakatan atas tujuan bersama dalam suatu kelompok masyarakat. Faksionalisme justru menunjukkan ketidaksepakatan atas cara kerja dominan dalam mencapai tujuan bersama (Siegel dan Beals, 1960). Pemahaman faksi yang demikian menjadi pendekatan konseptual untuk menjelaskan peran BM sebagai exit institution dalam masyarakat Minahasa pasca reformasi.

Pembahasan tentang peran BM sebagai exit institution menarik untuk dibahas karena beberapa alasan. Alasan pertama adalah konteks kehadiran BM cukup berbeda dengan beberapa studi terdahulu tentang kelompok vigilante. Studi Wilson (2010; 2018) menjelaskan kelompok vigilante lahir sebagai upaya "menantang" negara dalam penggunaan kekerasan di akar rumput. Penjelasan Wilson (2018) tentang peran 
kelompok vigilante seperti FPI dan FBR di Jawa (Jakarta) dikerangkai dalam konteks perebutan akses ekonomi politik antara negara dan masyarakat melalui kekerasan. Temuan Wilson menunjukkan hadirnya legitimasi baru atas penggunaan kekerasan oleh kelompok vigilante di Indonesia pasca reformasi. Legitimasi ini didapatkan dari klaim atas identitas primordial, baik etnis maupun agama (Wilson, 2018). Kelompok vigilante di era pasca reformasi mampu memanfaatkan klaim legitimasi tersebut untuk mengatur kembali posisi tawarnya-yang sempat melemah di era Orde Baru-terhadap negara pasca reformasi (Wilson, 2010; 2018).

Selain itu, studi Okamoto dan Hamid (2008) menjelaskan contoh kasus hadirnya kelompok vigilante di era pasca reformasi melalui kekuatan "elit lokal". Kasus Banten menunjukkan terbangunnya relasi patron-klien dalam kelompok vigilante di tingkat lokal dengan Jawara sebagai patron (Okamoto dan Hamid, 2008). Hubungan patronase ini tidak hanya terjadi di Banten. Beberapa tempat di Indonesia pasca reformasi seperti Lombok juga mengalami gejala serupa dalam studi Okamoto dan Rozak (2006). Hubungan patronase elit lokal dan kelompok vigilante dalam temuan Okamoto dan Razak (2006) bekerja untuk merebut maupun mengelola akses ekonomi politik di tingkat 
lokal. Berbeda dengan beberapa studi terdahulu, kasus BM menjelaskan kehadiran kelompok vigilante sebagai faksi dari dalam institusi keagamaan.

Alasan kedua adalah studi terdahulu tentang kelompok etnis Minahasa tidak memberikan tinjauan mendalam tentang dinamika kelompok vigilante dan gereja. Henley et.al. (2007) dan Sumampouw (2015) hanya menyinggung sekilas peran BM sebagai respons atas kelahiran FPI yang membawa agenda Islamisasi. Kosel (2010) dan publikasi terbaru Karim (2020) telah memberikan tinjauan historis yang bermanfaat untuk memahami peta jejaring, aktor utama, dan peran BM sebagai divisi keamanan dalam pelaksanaan Kongres Minahasa Raya (KMR) I di Sulawesi Utara. Berbagai penjelasan tersebut tidak menyinggung alasan kehadiran kelompok vigilante dan hadirnya penggunaan kekerasan di tengah metode diskursif yang secara dominan diupayakan oleh GMIM. Karenanya, peran BM dalam tulisan ini didudukkan dalam konteks yang lebih besarterutama konteks konflik Poso-untuk dapat melihat upaya kekerasan menjadi alternatif di tengah dominasi cara diskursif GMIM dalam menjaga keminahasaan. Bertolak dari berbagai penelitian terdahulu, penelitian ini ingin melihat kelompok vigilante sebagai fenomena 
faksionalisme dalam masyarakat Minahasa yang terjadi pasca reformasi.

Penelitian ini merupakan penelitian kualitatif dengan menggunakan studi kasus. Wawancara dilakukan dengan beberapa narasumber, di antaranya tokoh dan pengurus BM yang berpengaruh sejak awal pendiriannya. Selain itu, wawancara juga dilakukan dengan masyarakat yang terlibat secara langsung maupun tidak langsung dalam Konflik Poso III.10 Wawancara dilakukan di Manado, Tondano (Kab. Minahasa), dan Gorontalo dalam rentang waktu akhir bulan Desember 2019 hingga bulan Januari 2020 untuk memberikan beberapa informasi penting dalam tulisan ini.

\section{MENEMUKAN JALAN KELUAR BARU}

Ada empat hal yang akan diuraikan di sini, yaitu berpisahnya BM dari GMIM pasca KMR I, keterlibatan BM dalam konflik Poso yang menegaskan wataknya sebagai kelompok vigilante, terlembaganya BM sebagai

10 Beberapa tokoh dan pengurus BM-kemudian berubah menjadi Brigade Manguni Indonesia (BMI)-yang diwawancarai antara lain Dicky Maengkom (Ketua umum Brigade Manguni pasca KMR I), Deany Keintjem (Sekretaris Jenderal Brigade Manguni Indonesia), Corneles Mononimbar (Bendahara Umum Brigade Manguni Indonesia), dan Freddy Turalaki (Panglima Brigade Manguni Indonesia). Beberapa narasumber yang terlibat dalam konflik Poso ketiga tidak ingin disebutkan namanya, antara lain JR (saksi mata kehadiran BM secara fisik dalam konflik Poso), BP (bagian dari pasukan Kristen yang terlibat dalam beberapa momen konflik Poso), dan SS (warga Manado yang menerima ajakan untuk bergabung dalam konflik Poso ketiga). 
faksi yang terpisah dari GMIM, dan peran BM sebagai exit institution melalui beberapa pertimbangan dalam menjaga Keminahasaan di era pasca reformasi.

\section{BERPISAHNYA BM DARI GMIM PASCA KMR I}

Kondisi sosial politik di Indonesia pasca reformasi memperlihatkan kecenderungan menguatnya sentimen identitas primordial. Sidel (2007) menjelaskan bahwa usaha Islamisasi sejak periode 1990-an menemui puncaknya di era pasca reformasi. Selain konflik komunal, contoh Islamisasi yang terjadi pasca reformasi adalah usaha penambahan tujuh kata dalam amandemen konstitusi. ${ }^{11}$ Bertrand (2004) menilai menguatnya sentimen identitas primordial yang demikian menjadi momen negosiasi posisi kelompok etnis dalam sebuah negara-bangsa.

Salah satu kelompok etnis yang terlibat dalam proses "negosiasi" ini adalah kelompok etnis Minahasa melalui pelaksanaan KMR I pada tahun 2000 (Karim, 2020). KMR I hadir sebagai respons atas wacana pengembalian

11 Penambahan tujuh kata yang dimaksud adalah tambahan pada bagian: "Ketuhanan Yang Maha Esa dengan kewajiban menjalankan syariat Islam bagi pemeluknya.” Lebih lanjut tentang KMR I, lihat: Karim, Abdul Gaffar. (2020). Menegosiasikan Ulang Indonesia: Perubahan Politik dan Peran Lembaga-lembaga Agama di Manado dan Sumenep dalam Era Awal Reformasi (19992004). Yogyakarta: Diva Press. 
tujuh kata dari piagam Jakarta ke dalam pembukaan Undang-Undang Dasar 1945 yang digulirkan oleh politisi dari kelompok partai berbasis Islam (Karim, 2020). ${ }^{12}$ Wacana penambahan tujuh kata ini menyebabkan keminahasaan yang berkelindan dengan identitas Kristen menjadi berbeda dan rentan "dipinggirkan" melalui agenda Islamisasi dalam skala nasional. Elit GMIM dinilai oleh Karim (2020) mampu merespons hal tersebut melalui peran diskursif untuk menggagalkan Islamisasi yang diupayakan oleh elit politik di Jakarta. Melalui peristiwa KMR I, GMIM mampu untuk mewakilkan respons komunitas Minahasa-Kristen atas perubahan sosial yang terjadi pasca reformasi.

Kosel (2010) dan Karim (2020) mepandang momen KMR I sebagai awal kehadiran BM dalam bentuk seksi keamanan. Karim (2020) bahkan lebih spesifik menjelaskan kehadiran Permesta secara simbolik dapat dirasakan melalui kehadiran BM. ${ }^{13}$ Akan tetapi, studi terdahulu hanya menunjukkan keterlibatan BM dalam KMR I. Pengamatan Karim (2020) hanya menekankan

12 Wacana ini merupakan bagian dari rencana untuk merubah alinea keempat bagian "Ketuhanan Yang Maha Esa” dengan menambahkan tujuh kata dari Piagam Jakarta yakni “...dengan kewajiban menjalankan syariat Islam bagi pemeluk-pemeluknya."

13 Permesta (Perjuangan Rakyat Semesta) merupakan gerakan politik yang dipimpin oleh Ventje Sumual-seorang elit militer dari Minahasa-pada tahun 1957. Salah satu bagiannya adalah tentara Permesta yang menggunakan dengan seragam serba hitam. Lebih lanjut tentang Permesta, lihat: Barbara Sillars, Harvey. (1989). Permesta: Pemberontakan Setengah Hati (Terj.). Jakarta: Pustaka Utama Grafiti. 
BM dalam kerangka kerja GMIM selama KMR I melalui kontrol elit GMIM itu sendiri, seperti Pnt. (Penatua) Marhany Pua $^{14}$ dan Dolfie Maringka sebagai Tonaas Wangko atau ketua umum BM. Namun, pengamatan tersebut tidak mampu memindai momen KMR I dan setelahnya sebagai awal berpisahnya BM dari GMIM. Momen KMR I justru menjadi kesempatan bagi BM untuk menilai dan memanfaatkan titik keterbatasan GMIM.

Indikator keberhasilan dari peran diskursif GMIM yang diuji oleh kelompok kecil bernama BM saat itu adalah kemampuannya menjaga keamanan komunitas Minahasa-Kristen dari konflik komunal di beberapa lokasi, salah satunya Poso. Walaupun momen KMR I berakhir dengan keberhasilan GMIM dalam menjaga komunitas Minahasa-Kristen di tengah upaya Islamisasi melalui jalur parlementer (Karim, 2020), namun di sisi lain, peran diskursif GMIM tidak cukup kuat untuk menjaga komunitas Minahasa-Kristen dari dampak langsung konflik komunal. Peran diskursif GMIM tidak mampu membendung dampak dari konflik Poso pertama dan kedua yang memakan banyak korban dari kelompok Kristen (Aragon, 2001; Aditjondro, 2004). Karena itu,

14 Penatua (disingkat: Pnt.) merupakan sebutan bagi pejabat posisi struktural dalam kepengurusan GMIM. 
tidak mengherankan jika salah seorang tona'as, ${ }^{15}$ Deany Keintjem, di kediamannya pada tanggal 29 Desember 2019 turut menegaskan bahwa:

"Torang dari pertama memang beda dengan dorang gereja-gereja sama deng itu PGI. Dorang itu cuma salaman deng senyum-senyum di TV, konferensi pers, kong abis itu apa? Torang mo ibadah tetap susah. Nyanda guna." "(Kami sejak awal memang berbeda [cara kerja] dengan gereja-gereja seperti contohnya PGI [Persatuan Gereja-gereja Indonesia]. Mereka hanya bersalaman dan senyum di depan TV, tapi setelah itu apa? Kita [orang Kristen] mau ibadah tetap susah. Tidak berguna).”

Penilaian ini menunjukkan kegagalan gereja, khususnya GMIM, dari sudut pandang kelompok BM dalam menjaga keminahasaan di tengah konflik. Karena itu, peristiwa KMR I dapat dipertimbangkan sebagai momen awal BM dalam mengajukan ketidaksepakatan atas dominasi cara kerja diskursif GMIM. Ketidaksepakatan ini diikuti dengan berpisahnya BM dari GMIM yang dianggap terbatas dalam melindungi kelompok Minahasa-Kristen. Pemisahan ini juga terlihat melalui terbentuknya jejaring dan elit baru yang mampu untuk menentukan sikap BM pasca KMR I. Jabatan Tona'as Wangko yang sebelumnya diketuai oleh Dolfie

15 Tona'as merupakan sebutan bagi pemangku jabatan struktural dalam struktur kepengurusan Brigade Manguni. 
Maringka (Karim, 2020), telah tergantikan oleh Dicky Maengkom pasca KMR I dilaksanakan.

Maengkom merupakan "tokoh informal" dari Jakarta yang secara tidak langsung disokong oleh jejaring militer pusat untuk kembali ke Manado di pertengahan tahun 2000 (Kosel, 2010). Alasan penting dari tergesernya posisi Maringka disebabkan karena ketidakmampuan untuk bersikap secara konfrontatif terhadap aksi milisi Islam di wilayah konflik yang merugikan kelompok Kristen. Penjelasan terkait alasan ini didapatkan dari wawancara bersama Maengkom di Manado pada Bulan Januari 2020. Maengkom (2020) menilai bahwa Maringka merupakan sosok "politisi" yang kompromis dan tidak pantas menjadi pemimpin BM. Beroperasinya jejaring dan elit baru BM pasca KMR I semakin ditegaskan melalui keputusan BM untuk terlibat secara langsung dalam konflik Poso ketiga.

\section{KONFLIK POSO KETIGA}

Konteks konflik Poso ketiga di pertengahan tahun 2000 menjadi awal dari penggunaan kekerasan oleh BM. Konflik Poso terdiri dari tiga periode yang berlangsung sejak 1998-2001. Periode konflik yang menjadi pembahasan dalam bagian ini adalah konflik 
Poso ketiga. McRae (2008) menilai konflik Poso ketiga merupakan puncak dari dua periode konflik sebelumnya. Konflik Poso ketiga menjadi puncak dari dua konflik sebelumnya karena telah tereskalasi menjadi konflik horizontal antar-identitas keagamaan, dan melibatkan pendukung dari masing-masing pihak, baik Islam maupun Kristen dari luar Poso untuk datang berkonflik di Poso (Aditjondro, 2004). Aragon (2001) dan Aditjondro (2004) juga mencatat bahwa konflik Poso ketiga merupakan momentum balas dendam dari pihak Kristen kepada pihak Islam (Laskar Jihad) yang dianggap telah "membantai" banyak korban dari komunitas Kristen dalam dua konflik Poso sebelumnya. Kesempatan ini dimanfaatkan dengan baik oleh BM melalui keterlibatannya dalam konflik Poso ketiga. Keinginan "balas dendam” tidak mampu diartikulasikan oleh gereja dalam situasi konflik. Hal ini tercermin oleh sebuah anekdot anonim yang beredar dalam komunitas Kristen selama masa konflik Poso ketiga sebagai berikut.

"So dua kali"

"(Sudah dua kali)"

Ketika meletus kerusuhan Poso pertama dan kedua yang terjadi memakan banyak korban orang-orang kristen, banyakjemaatgerejaingin melampiaskan kemarahannya dan seorang pendeta berusaha menenangkan jemaat 


$\begin{array}{ll}\text { Pendeta } & \text { "Sodara-sodara, torang } \\ & \text { samua ba sabar jo, biar nanti } \\ & \text { Tuhan yang balas." } \\ & \text { "Saudara-saudara, kita } \\ & \text { semua bersabar saja, biarlah } \\ & \text { Tuhan yang membalas } \\ & \text { semuanya.)" } \\ & \text { "Pak pendeta, ini so dua kali } \\ & \text { Tuhan nyanda balas-balas. } \\ & \text { Biarjo torang yang balas!" } \\ \text { "Pemaat } & \text { (Pak pendeta, ini sudah dua } \\ & \text { kali [kerusuhan] tapi Tuhan } \\ & \text { tidak pernah membalasnya. } \\ & \text { Biar kami saja yang } \\ & \text { membalasnya!)" }\end{array}$

Dan pendeta pun terdiam mendengarnya...

Keterlibatan BM dalam konflik Poso ketiga diikuti dengan semakin vitalnya sosok Dicky Maengkom. Maengkom menjadi penting karena kemampuannya mengonsolidasikan pasukan yang dipersiapkan untuk terlibat dalam konflik Poso ketiga (Turalaki, 2020). Tona'as Freddy Turalaki yang ditemui di Manado pada bulan Januari 2020 mengungkapkan bahwa:

"Waktu itu memang banya antar lorong deng kampung bakalae. Tapi, cuma tu Dicky Maengkom yang bole se satu dorang samua. Dia no cuma da pi pangge pa dorang; daripada torang baku se-mati, mending torang 
baku bunuh, baku potong jo deng dorang tu islam-islam dari Jawa."

"(Pada masa itu banyak perkelahian antar gang dan kelurahan. Tapi, hanya Dicky Maengkom yang bisa mempersatukan mereka semua. Dia hanya memberi pesan; daripada kita [orang Minahasa] saling bunuh, lebih baik kita berperang [saling bunuh] dengan mereka, kelompok [milisi] Islam dari Jawa)."

Kemudahan untuk merekrut anggota BM untuk terlibat dalam konflik Poso juga didukung oleh gagalnya elit GMIM dalam membendung resonansi konflik di akar rumput. Walaupun elit GMIM berupaya mengonstruksi perdamaian di Sulawesi Utara secara dominan, namun pengaruhnya tidak dapat menjangkau komunitas peribadatan kolom dengan teritori yang lebih kecil, terpisah, namun menyebar secara luas di tingkat grassroot. Komunitas peribadatan kolom memiliki sikap yang lebih otonom dari sinode GMIM pusat terhadap situasi konflik. Salah satu contohnya adalah kesaksian SS, seorang pemuda Manado yang juga anggota jemaat GMIM yang tergabung dalam komunitas kolom. SS ikut membagikan ceritanya saat ditemui di Kecamatan Tikala, Manado pada bulan Januari 2020. Kesaksian SS menceritakan pesan yang disampaikan dalam setiap sesi khotbah peribadatan kolom masa itu secara implisit mendorong pemuda Minahasa- 
Kristen untuk berangkat ke wilayah konflik. Pesan yang selalu disampaikan adalah kisah tentang pembantaian "saudara" Kristiani dalam konflik Poso. Kelompok Kristen dianggap terancam oleh keberadaan kelompok (milisi) Islam. Alasan untuk berangkat ke Poso juga menjadi semakin menguat karena banyak korban pihak Kristen merupakan keluarga Minahasa di perantauan. Alasan ini didapatkan melalui penjelasan BP di Tondano, pertengahan bulan Januari 2020 sebagai salah seorang anggota milisi dari pihak Kristen yang terlibat dalam Konflik Poso.

Kehadiran BM dalam konflik Poso ketiga tidak terlihat melalui pencantuman identitas "Brigade Manguni" secara eksplisit. Keterlibatan dan penggunaan kekerasan oleh BM dalam konflik Poso didapati melalui dua sumber berbeda yang saling mengonfirmasi. Sumber pertama merupakan temuan Bakker (2012) yang menjelaskan bahwa kehadiran pasukan BM di Poso pada pertengahan tahun 2000 beroperasi dengan nama pasukan kelelawar. Nama ini merujuk pada pakaian serba hitam yang digunakan. Sementara sumber kedua yang mengonfirmasi temuan Bakker (2012) adalah wawancara bersama JR di Gorontalo pada akhir Bulan Januari 2020 sebagai saksi mata saat pasukan kelelawar memasuki kota Poso. Keterangan JR menjelaskan 
kehadiran delapan orang berbaju hitam-hitam dengan senjata tajam tanpa atribut BM pada pukul tiga subuh waktu setempat.

Pasukan BM merupakan unit pasukan yang dilatih secara berbeda dari kelompok milisi Kristen lainnya dalam konflik Poso. Sangadji (2007) menjelaskan bahwa pasukan BM dilatih oleh "oknum" Kopassus AD (Komando Pasukan Khusus Angkatan Darat) dalam hal kemampuan fisik dan pemahaman kondisi "medan tempur”. Aditjondro (2004) mencatat bahwa momen serangan balasan kelompok Kristen-yang di dalamnya BM turut serta-berdampak pada kehancuran beberapa kecamatan berpenduduk mayoritas Muslim seperti kecamatan Lage dan Poso Pesisir di kota Poso. Konteks konflik Poso ketiga menjadi penegasan dari pentingnya menggunakan kekerasan sebagai solusi alternatif untuk merespons ancaman konflik terhadap komunitas Minahasa-Kristen.

\section{PASCA KONFLIK POSO}

Periode pasca konflik Poso menjadi momen penataan internal BM. Hal ini ditandai dengan terlaksananya forum Musyawarah Adat Wangko Nasional (Musawangnas) pertama pada tanggal 9 Maret 2002 di Bukit Inspirasi, 
Tomohon. ${ }^{16}$ Musawangnas menjadi momen penegasan kembali kekuatan Dicky Maengkom sebagai tona'as wangko atau ketua umum ormas BM. Posisi Maengkom sebagai ketua umum BM pasca musawangnas pertama menegaskan semakin kuatnya otoritas Maengkom yang mampu memobilisasi penggunaan kekerasan sejak kepulangannya di Manado pada tahun 2000. Hal ini juga ditunjang oleh posisi Maengkom yang sejak awal kepulangannya telah disokong oleh jejaring elit militer keturunan Minahasa (Kosel, 2010). Momen musawangas pertama mengindikasikan semakin vitalnya pengaruh jejaring ini melalui keterlibatan beberapa elit militer dalam struktur kepengurusan BM. Hal ini ditunjukkan oleh Kosel (2010) yang menemukan posisi mantan Pangkostrad (Panglima Komando Strategis Angkatan Darat) dan Danjen (Komandan Jenderal) Kopasus AD, Letnan Jenderal Purn. Prabowo Subianto, sebagai bagian dari Dewan Penasehat BM. ${ }^{17}$

16 Musawangnas merupakan forum musyawarah internal BM yang dilakukan secara periodik dalam lima tahun sekali. Musawangnas dilaksakanan untuk membahas urusan internal dan pemilihan ketua umum BM.

17 Walaupun Prabowo Subianto tidak dikenal sebagai pemeluk agama Kristen, namun Prabowo dapat terlegitimasi menjadi bagian dari BM sebagai ormas adat Minahasa karena memiliki ikatan keluarga Minahasa-Kristen dari sisi orang tua perempuan, Dora Sigar. Dari sisi orang tua perempuan, Prabowo memiliki jejaring keluarga "Sigar-Maengkom" yang merupakan nama keluarga Minahasa. Lebih lanjut tentang keterlibatan Prabowo dan Jenderal lainnya dalam BM lihat: Kosel, Sven. (2010) "Christianity, Minahasa Ethnicity, and Politics in North Sulawesi: Jerusalem's Veranda or Stronghold of Pancasila?” Dalam Susanne Schröter (Ed), Christianity in Indonesia: Perspectives of Power, (pp. 291-22). LIT Verlag Münster. 
Pasca konflik Poso, BM mulai membuka beberapa pengurus daerah di luar wilayah Sulut. Periode ini menjadi awal bagi BM untuk menjalin hubungan dengan ormas lainnya-walaupun masih terbatas pada ormas adat dan keagamaan non-Islam-seperti yang terjalin dengan kelompok masyarakat Dayak di Kalimantan melalui koordinasi tona'as korwil Kalimantan, Fary Malonda. Penataan lain yang dilakukan adalah dengan melakukan perubahan yang cukup fundamental di tahun 2010 melalui perubahan nama BM menjadi BMI (Brigade Manguni Indonesia) pada musawangnas kedua. Penambahan diksi "Indonesia" menjadi tanda dibukanya pintu bagi masyarakat non-Minahasa dan non-Kristen untuk bergabung dengan BMI. Secara sekilas, terdapat perubahan orientasi dari BM menjadi BMI yang cukup kontras jika dibandingkan sejak keterlibatannya dalam konflik Poso hingga musawangnas kedua. Namun, yang menjadi catatan penting adalah BMI tetap beroperasi dengan logika dan cara kerja yang erat dengan kekerasan. Hal mendasar yang dijaga oleh BMI sejak awal adalah cara melihat kelompok lainterutama kelompok Islam dan imigran Jawa di kawasan Sulawesi-sebagai kelompok yang dapat mengancam kelompok Minahasa-Kristen melalui konflik antar-etnis dan agama. 
Meskipun respons melalui penggunaan kekerasan terhadap kelompok lainnya semakin surut pasca konflik Poso, BM merasa perlu untuk melekatkan citra "preman" dalam dirinya (Maengkom, 2020). Menurut Maengkom (2020) dalam wawancara yang dilakukan di Manado, citra preman harus ditampilkan dengan sengaja melalui penggunaan kekerasan-sekalipun tidak harus dalam bentuk fisik. Hal tersebut dianggap Maengkom sebagai langkah preventif untuk menurunkan risiko ancaman dari kelompok lain terhadap keminahasaan. Karenanya, proses keterbukaan BM tidak dapat dibaca semata-mata sebagai langkah awal untuk meninggalkan penggunaan kekerasan. Lebih dari itu, BM telah mengambil sebuah strategi pragmatik yang dirasa lebih efektif untuk menjaga kerentanan kelompok Minahasa-Kristen pasca konflik Poso ketiga.

\section{BRIGADE MANGUNI SEBAGAI EXIT INSTITUTION}

Tulisan ini menawarkan istilah exit institution untuk menjelaskan peran BM antara tahun 2000-2010. Istilah ini diambil dari pengamatan terhadap keberhasilan BM sebagai institusi yang mampu menawarkan jalan keluar dari dominasi cara kerja GMIM secara diskursif. Tawaran jalan keluar menyiratkan adanya kebuntuan aspirasi 
sebagian warga GMIM atas situasi konflik komunal pada pertengahan tahun 2000. Solusi atas kebuntuan aspirasi ini berhasil diartikulasikan oleh BM melalui penggunaan kekerasan. Karena itu, exit institution merupakan refleksi dari peran BM di era pasca reformasi sebagai institusi yang mampu menawarkan jalan keluar menuju cara kekerasan dalam menjaga keminahasaan. Lebih lanjut, BM berhasil melegitimasi kekerasan sebagai cara kerja alternatif dalam bentuk kelompok vigilante yang semakin otonom dari GMIM.

Istilah ini ditawarkan dengan menimbang beberapa hal sebagai berikut. Pertimbangan pertama adalah kemampuan BM dalam melihat dan memanfaatkan keterbatasan GMIM. Keterbatasan ini dapat dimanfaatkan bahkan di saat GMIM sedang memiliki legitimasi yang kuat dan tampak jelas melalui beberapa peristiwa seperti dalam KMR I (Karim, 2020), maupun keberhasilannya menginisiasi kerja sama lintas kelompok di Sulawesi Utara (Henley et.al., 2007). Pilihan cara kerja GMIM untuk menjaga keminahasaan selalu menampilkan pola diskursif yang dominan dan diulang secara terus-menerus dalam berbagai periode. Hal ini bahkan dapat ditemukan jauh sebelum era pasca reformasi yang ditandai berbagai konflik komunal dan menguatnya sentimen identitas primordial. Karim 
(2020) telah mencatat kehadiran cara kerja diskursif GMIM saat terjadi gejolak politik di masa peralihan kuasa di akhir dekade 1960-an. Dalam periode tersebut, GMIM memilih untuk memainkan cara diskursif dalam menunjukkan sikapnya secara implisit terhadap situasi politik saat itu. Sebagai implikasinya, GMIM menjadi lebih kompromis dalam menyikapi perubahan politik di akhir pemerintahan Sukarno.

Cara kerja yang sama berlanjut ketika GMIM dihadapkan pada kondisi politik pasca reformasi. Slogan torang samua basudara yang cukup terkenal bahkan tidak lepas dari konstruksi perdamaian yang dibangun melalui dominasi GMIM secara diskursif. Dominasi ini dapat diamati sekalipun patut terdapat aktor-aktor lainnya yang tidak memiliki peran sebesar GMIM (Sumampouw, 2015). Akan tetapi, dominasi cara diskursif dapat terjadi karena GMIM tidak memiliki pilihan cara lain untuk merespons perubahan politik. Keterbatasan justifikasi teologis sebagai dasar legitimasi membuat GMIM hanya dapat melakukan usaha persuasi secara diskursif tanpa mampu melakukan koersi melalui penggunaan kekerasan. Hal ini membuat GMIM tidak mampu mengartikulasikan aspirasi sebagian komunitas Minahasa-Kristen untuk menggunakan kekerasan. Ketidaksepakatan BM terhadap GMIM turut 
mendisrupsi peran GMIM yang sejak awal telah menjadi struktur dominan dalam komunitas Minahasa.

Pertimbangan kedua dalam menilai kehadiran BM sebagai exit institution di rentang tahun 2000-2010 adalah keberhasilan BM dalam merekonstruksi identitas keminahasaan di era pasca refromasi. Rekonstruksi ini berfungsi untuk memberikan legitimasi bagi kelompok vigilante dalam menggunakan cara-cara kekerasan. Usaha rekonstruksi ini terlihat dengan cara melihat sejarah Minahasa pra-modern sebagai sumber legitimasi dalam merespons ancaman terhadap keminahasaan di era pasca reformasi. Secara simbolik, hal ini tampak jelas melalui penggunaan istilah manguni, tona'as, maupun ritus-ritus adat secara terbuka yang hanya dapat ditemukan dalam sistem kepercayaan dan struktur sosial masyarakat Minahasa pra-modern (lihat Henley, 1993).

Hal ini menunjukkan bahwa peran misionaris NZG tidak turut menghapuskan sepenuhnya ingatan masa lampau tentang kehidupan masyarakat Minahasa "pramodern" jauh sebelum terbentuknya identitas "bangsa" modern seperti temuan Henley (1993). Keberhasilan merekonstruksi identitas Minahasa menjadi lebih radikal telah membuat penggunaan kekerasan oleh BM dapat terlegitimasi atas nama keminahasaan. 
Rekonstruksi identitas Minahasa memberikan legitimasi atas beroperasinya cara kerja maupun bentuk kelembagaan BM yang berbeda dari GMIM. Legitimasi ini ditegaskan oleh kehadiran BM yang tetap eksis pasca periode konflik komunal melalui proses pelembagaan kelompok vigilante.

\section{KONTEKS ALTERNATIF}

Peran BM dalam kurun waktu 2000-2010 dapat memberikan kontribusi penting dalam studi tentang kelompok vigilante di Indonesia pasca reformasi. Kontribusi khusus dari peranan BM adalah perbedaan konteks terbentuknya kelompok vigilante. Dalam studi-studi terdahulu, kehadiran kelompok vigilante merupakan implikasi dari monopoli negara atas kekerasan di tengah masyarakat. Wilson (2010) memberikan penjelasan akan pertautan antara kelompok vigilante dan kekuasaan formal negara. Melalui contoh FPI dan FBR, Wilson (2010) memberikan tinjauan salah satunya dengan konsep relasi kelompok vigilante dan negara ala Schulte-Bockholt (2006). Schulte-Bockholt (2006) menilai peranan dan signifikansi kelompok vigilante ditentukan oleh tingkat kekuatan monopoli negara atas kekerasan yang legal. Wilson (2010) mengamati kehadiran FPI dan FBR setelah Orde Baru 
difasilitasi melalui perbaikan daya tawar kelompok vigilante terhadap otoritas negara yang lemah. Dalam relasi tersebut, terjadi distribusi akses ekonomi politik dari negara yang dipertukarkan dengan penggunaan kekerasan oleh kelompok vigilante secara transaksional.

Wilson (2010b) juga menjelaskan kelompok vigilante di Indonesia pasca reformasi mampu terlibat dalam perebutan kekuasaan negara melalui mekanisme demokrasi formal. Peran kelompok vigilante di era pasca reformasi bahkan mampu untuk menantang monopoli negara atas kekerasan yang legal di akar rumput (Wilson, 2018). Analisis Wilson menunjukkan bahwa kehadiran kelompok vigilante berada dalam relasi vertikal antara masyarakat dan negara. Tantangan kelompok vigilante terhadap otoritas negara juga diikuti dengan motif perebutan kuasa atas sumber daya ekonomi dan politik pasca reformasi (lihat Wilson, 2010). Karena itu, penilaian Wilson menunjukkan bahwa konteks kehadiran kelompok vigilante tidak akan lepas dari kerangka kontestasi antara negara dan masyarakat.

Konteks BM menunjukkan kehadiran kelompok vigilante berbeda dengan beberapa pengamatan terdahulu. Penjelasan peran BM mengindikasikan bahwa alasan kehadiran kelompok vigilante justru dapat ditemukan di tengah masyarakat. Hal ini 
ditunjukkan melalui proses faksionalisme. Kehadiran BM tidak memiliki keterkaitan secara langsung dengan perebutan kekuasaan formal negara pasca reformasi. Karena itu, kasus BM menjadi konteks alternatif di tengah dominasi konteks perebutan sumber daya ekonomi politik antara negara dan masyarakat dalam menjelaskan peran kelompok vigilante di Indonesia. Kehadiran BM juga menunjukkan ketiadaan relasi antara negara dan masyarakat secara langsung sebagai faktor utama terbentuknya kelompok vigilante. Kasus BM menekankan pentingnya memahami konteks perubahan tata kuasa dalam masyarakat untuk menjelaskan alasan kehadiran kelompok vigilante.

Konteks ini memberikan pijakan penting dalam menjelaskan terbentuknya klaim atas identitas sebagai dasar legitimasi bagi peran kelompok vigilante pasca reformasi. Wilson (2018) telah memberi penjelasan bahwa identitas primordial sebagai dasar legitimasi merupakan hal penting karena membuat penggunaan kekerasan menjadi adaptif terhadap perubahan sosial. Bagi Wilson, klaim atas identitas hanya menjadi motor bagi kelompok vigilante untuk melegitimasi perannya dalam perebutan sumber daya. Dengan adanya klaim identitas, maka kelompok vigilante memiliki daya tawar yang baru dan lebih kuat terhadap negara 
pasca reformasi (Wilson, 2010). Akan tetapi, Wilson tidak memberi penjelasan lebih lanjut pada proses terbentuknya identitas sebagai dasar legitimasi dari interaksi horizontal di tengah masyarakat.

Kasus BM secara eksplisit menunjukkan proses terbentuknya identitas primordial dari akar rumput sebagai dasar legitimasi bagi kelompok vigilante untuk penggunaan kekerasan. Legitimasi BM dalam membawa identitas keminahasaan didapatkan dengan memanfaatkan keterbatasan cara kerja institusi keagamaan di tengah konflik komunal. Dengan kata lain, hampir tidak mungkin untuk memahami alasan kehadiran dan peran BM tanpa memperhatikan menguatnya sentimen primordial-yang salah satunya berwujud dalam konflik Poso ketiga-dan dampaknya terhadap keminahasaan sebagai identitas komunal. Dengan demikian, kasus BM menunjukkan bahwa terdapat konteks alternatif untuk melacak alasan hadirnya peran dan legitimasi bagi kelompok vigilante berbasis identitas primordial di Indonesia pasca reformasi. 
Dalam catatan Henley et.al. (2007), peran dominan GMIM ketika merespons ancaman konflik tidak mengalami friksi dan resisten yang nyata dari berbagai pihak. Henley et.al. (2007) berkesimpulan bahwa masyarakat sipil-terutama GMIM-di Sulawesi Utara dengan dominasi komunitas Minahasa-Kristen mampu untuk membuat komitmen yang kuat terhadap perdamaian. Komitmen ini ditunjukkan melalui proses kerja sama antar-aktor masyarakat sipil dalam merespons resonansi konflik dari wilayah tetangga. Walaupun demikian, Henley et.al. (2007) memberi prasyarat bahwa kerja sama antar-tokoh lintas agama dan kelompok akan sulit dicapai jika tidak terdapat komitmen yang sama terhadap perdamaian serta otoritas yang tidak timpang dari para tokoh terhadap pengikutnya.

Catatan Henley et.al. (2007) menjadi pintu masuk untuk menjelaskan tidak tercapainya prasyarat tersebut dalam kasus BM. Kasus BM menunjukkan sebaliknya bahwa terdapat pihak yang mampu mendisrupsi proses kerja sama oleh struktur dominan dalam komunitas Minahasa-Kristen. Oleh Siegel dan Beals (1960) kegiatan disruptif atas cara kerja struktur dominan dalam masyarakat menandakan terjadinya faksionalisme. Dengan meminjam konsepsi Siegel dan Beals (1960), 
terdapat dua komponen yang patut dipertimbangkan dalam menjelaskan terbentuknya faksi dalam GMIM. Komponen pertama adalah posisi kelompok etnis Minahasa terhadap lingkungan di luarnya (stress). Untuk memindai terbentuknya faksi GMIM dibutuhkan keterkaitan konteks konflik komunal dan keminahasaan secara langsung. Temuan Henley et.al. (2007) cenderung memperlihatkan batasan antara keminahasaan dan konflik komunal secara langsung. Batasan ini tampak melalui usaha menjaga keminahasaan dari konflik dari wilayah tetangga diisolasi dalam konteks spasial Sulawesi Utara (lihat Henley et.al., 2007).

Isolasi yang demikian memosisikan GMIM menjadi dominan karena cara-cara diskursif menjadi solusi atas resonansi konflik. Pengamatan tersebut telah menempatkan posisi BM sebagai bagian yang tunduk dalam keseluruhan cara-cara diskursif GMIM tanpa mampu memanfaatkan keterbatasannya. Karena itu, untuk menjelaskan keterbatasan GMIM diperlukan pengamatan yang melihat hubungan antara konflik Poso dan implilkasinya terhadap keminahasaan secara langsung. Jika keminahasaan dan konflik Poso dikaitkan secara langsung, maka dapat diketahui dominasi GMIM hanya mampu beroperasi dalam wilayah administratif Sulawesi Utara. GMIM tidak mampu untuk merespons 
kerentanan identitas Minahasa-Kristen yang berada di luar batas administratif tertentu. Karena itu, cara diskursif tidak dapat berdampak maksimal untuk merespons konflik Poso.

Komponen kedua dalam menjelaskan terbentuknya faksi adalah perbedaan pilihan cara dalam suatu kelompok untuk mencapai tujuan bersama (strain). Awal perbedaan ini dapat dilihat dari kebuntuan aspirasi warga GMIM yang menginginkan penggunaan kekerasan sebagai respons atas konflik horizontal. Pilihan untuk keluar dari cara diskursif menjadi sulit bagi GMIM karena keterbatasan justifikasi teologis gereja dalam menggunakan kekerasan. GMIM tidak memiliki pilihan untuk menampilkan keminahasaan yang damai selain dengan menampilkan wajah dominan yang ModernBarat-Kristen (lihat Yulianto, 2015). Sebagai akibatnya, aspirasi sebagian warga GMIM untuk menggunakan kekerasan menjadi buntu dalam kerangka yang demikian. Kegagalan GMIM dalam mengartikulasikan aspirasi untuk menggunakan kekerasan berujung pada usaha merekonstruksi wajah keminahasaan yang lain dari wajah dominan. Rekonstruksi wajah keminahasaan menjadi lebih radikal telah menjadi dasar legitimasi bagi faksi baru dari dalam GMIM. Legitimasi ini membuat faksi BM mampu untuk keluar dari cara diskursif 
dan beralih menjadi penggunaan kekerasan dalam merespons ancaman terhadap komunitas MinahasaKristen pasca reformasi.

\section{KESIMPULAN}

Terdapat sejumlah alasan yang menunjukkan alasan kehadiran BM sebagai exit institution di periode pasca reformasi. Faktor pertama adalah peran GMIM untuk menjaga keminahasaan hanya terbatas dalam batasan administratif Provinsi Sulawesi Utara, sedangkan keminahasaan sendiri tidak dapat dibatasi secara spasial. ${ }^{18}$ Hal ini ditunjukkan oleh konflik komunal di Poso-di luar wilayah administratif Sulawesi Utaramampu menjadi alasan bagi kelompok vigilante untuk terlibat dalam penggunaan kekerasan yang terlegitimasi. Pertimbangan BM dalam melihat posisi etnis Minahasa yang terhubung secara langsung dengan konflik komunal di Poso mampu menjelaskan keterbatasan spasialadministratif gereja sebagai faktor dari kehadiran faksi dalam menjaga keminahasaan.

18 Temuan Swazey (2008) sebelumnya juga menunjukkan bahwa keminahasaan tidak dapat dibatasi oleh batasan spasial tertentu. Walaupun demikian, penelitian Swazey hanya membahas keminahasaan yang dirawat melalui peran gereja dalam kehidupan masyarakat Kristen. Lebih lanjut, lihat: Swazey, Kelly. (2008). "Carrying Culture and (Re)Creating Nation Through Christianity: Minahasa Culture and Identity in Transnational Indonesia Churches in New England." Master of Art Thesis, University of Hawai'I Manoa. 
Faktor kedua yang menjelaskan alasan kehadiran BM adalah keterbatasan legitimasi GMIM dalam menentukan pilihan cara untuk menjaga keminahasaan dari usaha peminggiran. Legitimasi GMIM hanya terbatas dalam wajah keminahasaan yang modern, namun ditampilkan secara dominan. Proses ini menjadi dasar legitimasi bekerjanya peran gereja dalam komunitas MinahasaKristen (lihat Henley, 1993; Schouten, 1998; Yulianto, 2015). Namun, legitimasi yang demikian tidak mampu menyediakan peluang baru bagi hadirnya pilihan lain, seperti penggunaan kekerasan untuk memaksa agenda tertentu. Pilihan penggunaan kekerasan terwujud melalui rekonstruksi identitas keminahasaan yang lebih radikal sebagai dasar legitimasi baru. Rekonstruksi identitas keminahasaan mampu melegitimasi penggunaan kekerasan yang keluar dari wajah Minahasa yang Modern-Barat-Kristen. Kehadiran faksi dari dalam GMIM sebagai struktur dominan juga mengindikasikan terjadinya kontestasi atas identitas keminahasaan di era pasca reformasi.

Keminahasaan di era pasca reformasi tidak lagi dapat dipandang sebagai identitas yang dominan dengan aspek Modern-Barat. Kehadiran BM menunjukkan bahwa usaha menjaga identitas keminahasaan di era pasca reformasi tidak lagi dapat didominasi oleh peran GMIM. 
Peran BM sebagai exit institution telah merefleksikan terbukanya kesempatan bagi aktor di luar maupun dari dalam gereja (GMIM) untuk berkontestasi merumuskan berbagai pilihan cara baru dalam menjaga danmeminjam diksi Karim (2020)-menegosiasikan posisi komunitas Minahasa-Kristen yang rentan dipinggirkan dalam kondisi sosial-politik Indonesia pasca reformasi.

Dua faktor keterbatasan GMIM menyebabkan terbentuknya faksi BM dari dalam institusi keagamaan dengan peran sebagai exit institution. Peran exit institution menunjukkan kelompok vigilante seperti BM mampu menawarkan jalan keluar sekaligus mendisrupsi peran GMIM sebagai struktur dominan dalam masyarakat Minahasa-Kristen. Disrupsi ini tampak melalui penggunaan kekerasan oleh BM dalam Konflik Poso. Penggunaan kekerasan menjadi cara kerja yang mampu menantang peran diskursif GMIM. Hal ini menegaskan watak faksi menurut Siegel dan Beals (1960) yang mampu mendisrupsi peran struktur dominan dalam masyarakat. Kasus BM menunjukkan bahwa penjelasan tentang terbentuknya faksi dalam masyarakat dapat digunakan untuk melacak peran kelompok vigilante. Pendekatan faksionalisme belum pernah digunakan untuk menjelaskan kehadiran kelompok vigilante. Pendekatan tersebut memperlihatkan peran kelompok 
vigilante hadir di luar konteks relasi antara negara dan masyarakat yang cenderung digunakan dalam beberapa studi terdahulu. Karena itu, kasus BM dapat dipertimbangkan menjadi konteks alternatif dalam menjelaskan peranan kelompok vigilante di Indonesia pasca reformasi. 


\section{REFERENSI}

Aditjondro, George Junus. (2004). Kerusuhan Poso dan Morowali, Akar Permasalahan dan Jalan Keluarnya. Penerapan Keadaan Darurat di Aceh, Papua, dan Poso Dalam Pemilu 2004? Jakarta: ProPatria.

Aragon, Lorraine V. (2001). Communal Violence in Poso, Central Sulawesi: Where People Eat Fish and Fish Eat People. Indonesia 72. Ithaca: Cornell University. 4579.

Badan Pusat Statistik Propinsi Sulawesi Utara. (2000). Penduduk Sulawesi Utara (Termasuk Gorontalo) Hasil Sensus Penduduk 200o. Manado: Badan Pusat Statistik Propinsi Sulawesi Utara.

Bakker, Laurens. (2012). Organized Violence and the State: Evolving Vigilantism in Indonesia. Bijdragen tot de Taal-, Land-en Volkenkunde. Brill. 249-277.

Bertrand, Jacques. (2004). Nationalism and Ethnic Conflict in Indonesia. Cambridge: Cambridge University.

Fortes, M., dan E.E. Pritchard. (1940). African Political System. London: Oxford University Press.

Harvey, Barbara Sillars. (1989). Permesta: Pemberontakan Setengah Hati [Terj.]. Jakarta: Pustaka Utama Grafiti. 
Henley, David. (1993). Nationalism and Regionalism in Colonial Indonesia: The Case of Minahasa. Indonesia 55. Ithaca: Cornell University. 91-112.

Henley, David, Maria J.C. Schouten, dan Alex J. Ulaen. (2007). Preserving the Peace in Post-New Order Minahasa dalam Henk Schulte Nordholt dan Gerry van Klinken (Eds), Renegotiating Boundaries, (pp. 307-26). Leiden: KITLV Press.

Johnston, Les. (1996). What is Vigilantism? British Journal of Criminology 36. Oxford University Press. 220-36.

Karim, Abdul Gaffar. (2020). Menegosiasikan Ulang Indonesia: Perubahan Politik dan Peran Lembagalembaga Agama di Manado dan Sumenep dalam Era Awal Reformasi (1999-2004). Yogyakarta: Diva Press.

Kosel, Sven. (2010). Christianity, Minahasa Ethnicity, and Politics in North Sulawesi: Jerusalem's Veranda or Stronghold of Pancasila? dalam Susanne Schröter (Ed), Christianity in Indonesia: Perspectives of Power, (pp. 291-22). LIT Verlag Münster.

Makello, Ilham Daeng. (2010). Kota Seribu Gereja: Dinamika Keagamaan dan Penggunaan Ruang di Kota Manado. Yogyakarta: Ombak. 
Masaaki, Okamoto, dan Abdur Rozaki. (2006). Kelompok Kekerasan dan Bos Lokal di era Reformasi. Yogyakarta: IRE Press.

Masaaki, Okamoto, dan Abdul Hamid. (2008). Jawara in Power, 1999-2007. Indonesia 86. Cornell University Press. 109-38.

McRae, David Gregory. (2008). The Escalation and Decline of Violent Conflict in Poso, Central Sulawesi, 19982007. Thesis (Ph.D). Australia: Australian National University.

Nicholas, Ralph. W. (1966). Segmentary Factional Political System dalam Marc J. Schawrtz, Victor W. Turner, Arthur Tuden (Eds). Political Anthropology, (pp. 4960). Chicago: Aldine Publishing.

Sangadji, Arianto. (2007). The Security Forces and Regional Violence in Poso dalam Henk Schulte Nordholt dan Gerry van Klinken (Eds). Renegotiating Boundaries: Local Politics in Post-Suharto Indonesia, (pp. 25580). Leiden: KITLV Press.

Schouten, Maria J. C. (1998). Leadership and Social Mobility in a Southeast Asia Society: Minahasa 16771983. Leiden: KITLV Press. 
Scuhlte-Bockholt, Alfredo. (2006). The Politics of Organized Crime and the Organized Crime of Politics: A Study in Criminal Power. Lexingtoon Books.

Sidel, John T. (2018). Riots, Pogroms, Jihad: Religious Violence in Indonesia. Cornell University Press.

Siegel, Bernard J, dan Alan R. Beals. (1960). Conflict and Factional Disputes. The Journal of the Royal Anthropological Institute of Great Britain and Ireland. Royal Anthropological Institute of Great Britain and Ireland. 107-117.

Sumampouw, Nono. (2015). Menjadi Manado Torang Samua Basudara, Sabla Aer, dan Pembentukan Identitas Sosial. Yogyakarta: Gadjah Mada University Press.

Swazey, Kelly. (2008). Carrying Culture and (Re)Creating Nation Through Christianity: Minahasa Culture and Identity in Transnational Indonesia Churches in New England. Master of Art Thesis, University of Hawai'I Manoa.

van Klinken, Gerry. (2007). Communal Violence and Democratization in Indonesia: Small Town Wars. Routledge. 
Wilson, Ian. (2010). Reconfiguring Rackets: Racket Regimes, Protection and the State in Post-New Order Jakarta dalam Edward Aspinall dan Gerry van Klinken (Eds), The State and Illegality in Indonesia, (pp. 2396o). Brill.

Wilson, Ian. (2010b). The Rise and Fall of Political Gangsters in Indonesia Democracy dalam Edward Aspinall dan Marcus Mietzner (Eds). The Problem of Democratisation in Indonesia: Election, Institution and Society, (pp. 199-218). Singapore: ISEAS Publishing.

Wilson, Ian Douglas. (2018). Politik Jatah Preman: Ormas dan Kuasa Jalanan di Indonesia Pasca Orde Baru [Terj.]. Tangerang Selatan: Marjin Kiri.

Yulianto, Vissia Ita. (2015). Reframing Modernities in Contemporary Indonesia: Ethnographic Studies of Ideas of Center and Periphery on Sulawesi and Java. Berlin: Regiospectra Verlag. 


\section{WAWANCARA}

BP. Wawancara di Tondano, 18 Januari 2020.

JR. Wawancara di Gorontalo, 20 Januari 2020.

Keintjem, Deany. Wawancara di Gorontalo, 29 Desember 2019.

Maengkom, Dicky. Wawancara di Manado, 22 Januari 2020.

SS. Wawancara di Manado, 17 Januari 2020.

Turalaki, Freddy. Wawancara di Manado, 16 Januari 2020. 